\section{IN THE NEWS}

Don't shoot the messenger The release in late October of the Phillips report - the 18volume result of a three-year investigation into how Britain's bovine spongiform encephalopathy (BSE) crisis was handled sparked a wave of media coverage in the United Kingdom. The report concludes that ministers and civil servants were acting under the genuine belief that the risks of eating British beef were minimal. But there have been attempts by the British press to lay some of the blame on another doorstep - that of the scientists.

A feature in The Guardian, for example, preaches that "BSE is the latest crisis to dent public faith in those who should know better", citing genetically modified foods, fluoride in water and antibiotics in foods as other instances of scientific "scare stories". In the case of BSE, however, the article claims that scientists are under fire not for "their pure scientific method, or even their conclusions", but for "the way they allowed themselves and their opinions to be manipulated by civil servants".

Writing in The Independent on Sunday, Geoffrey Lean dubs the crisis "a kind of Stockholm syndrome where captives come to identify with those who take them hostage - in reverse. Seduced by a hazard they are supposed to be controlling, regulators come to believe that it poses no threat". He groups scientists among those who fell into this trap, but also speaks out against the "villification and marginalisation of ... dissident scientists", citing Professor Derek Bryce-Smith as an example. He, apparently, warned long ago about the dangers of leaded petrol - a far cry from BSE, but in the news again owing to the fuel crisis that has swept across Europe over the past few months

\section{How to lead a double life}

Just like W. E. Hill's famous optical illusion (see picture), ephrins have mastered the art of being simultaneously attractive and repulsive. Three papers, in Nature, EMBO Journal and The Journal of Biological Chemistry provide clues as to how these signalling molecules lead their double life.

Eph receptor tyrosine kinases and their membrane-tethered ligands, the ephrins, provide guidance cues for developing neurons and blood vessels. The classical view of ephrin signalling is that it mediates repulsion between ephrin-expressing and Ephexpressing cells, but this relationship doesn't always hold true. Johan Holmberg and colleagues found such a case when they knocked out the gene for ephrin-A5 in mice: some of the mice lacked brains because the neural tube had failed to close at the cranial end - probably due to failure of an adhesive, rather than a repulsive, signal.

In situ hybridization in wild-type mouse embryos revealed that ephrinA5 and three splice variants of its receptor, EphA7, are expressed at the edges of the cranial neural folds as the neural tube closes, and cells dissected from them adhered more tightly to EphA7-coated surfaces if they expressed ephrin-A5. But do all the EphA7 splice variants behave in the same way? In chemotactic assays, cells expressing full-length EphA7 actually repelled ephrin-A5, but when expression of a truncated splice form of EphA7 (EphA7-T1) was switched on, the repulsive effect was blocked. But there's more to this response than just inhibi-

tion of repulsion, because when cells expressing the two EphA7 variants were plated out on confluent layers of a mixture of ephrin- $\mathrm{A} 5^{+}$and ephrin-A5- cells, the cells expressing the EphA7-T1 grew preferentially on the ephrin- $\mathrm{A}^{+}$ cells, whereas those expressing the full-length receptor preferred ephrinA5 ${ }^{-}$cells. The most likely mechanism is that the truncated receptor acts in a dominant-negative manner, a model supported by the finding that EphA7-T1 expression reduces tyrosine phosphorylation of the full-length receptor.
Another peculiarity of ephrin signalling is that it's bidirectional: engagement of Eph receptors transmits signals to the ligand-expressing cells, as well as the receptor-expressing cells. This is all the more intriguing for the A-type ephrins, which are tethered by a glycosylphosphatidylinositol anchor. How can this transmit signals to the cell's interior? Davy and Robbins find that ephrinA5, activated by the extracellular

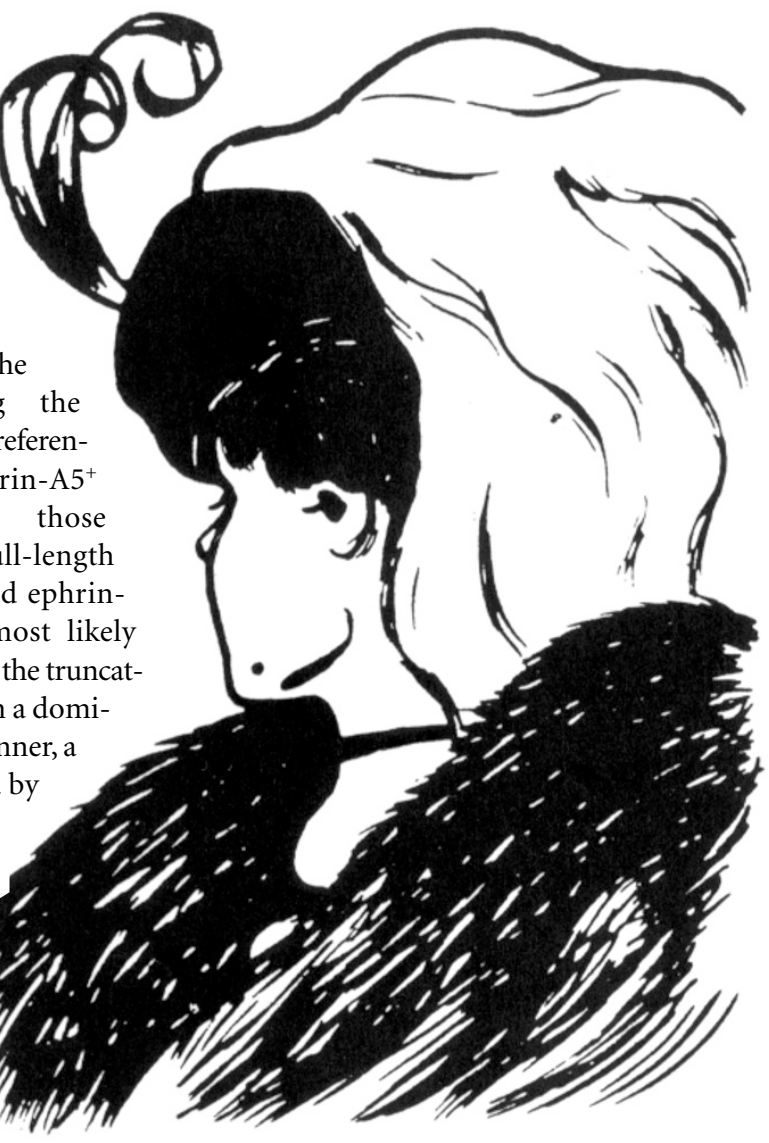

\title{
RNA LOCALIZATION
}

\section{She's got a ticket to ride}

Ash1p is a transcriptional repressor necessary for matingtype switching in budding yeast, and its messenger RNA is transported into the bud where the protein is ultimately needed. To get there, the mRNA rides into the bud along actin tracks, carried by the myosin V-type motor Myo4p. But how does the
RNA hang on to the motor? Ralf-Peter Jansen and colleagues now report in the EMBO Journal that they have found the missing link.

Genetic screens had determined that She $2 p$ and She $3 p$ are involved in ASH1 mRNA localization but what exactly do they do? Jansen and colleagues found, through a biochemical approach, that She2p is the long-sought RNA-binding protein, specific for ASH1 mRNA. Furthermore, they showed that She3p is an adaptor that binds She2p through its carboxyl terminus and Myo4p through its amino terminus. Whereas She $3 p$ is associated with this myosin motor constitutively, and can be transported into the bud even in the absence of $A S H 1$ mRNA, She2p needs to bind ASH1 mRNA to interact efficiently with She3p. 